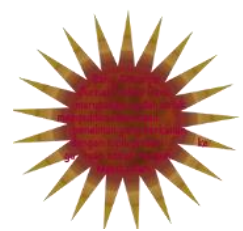

Sang Acharya: Jurnal Profesi Guru

Universitas Hindu Negeri I Gusti Bagus Sugriwa

Denpasar

http: //ejournal . uhnsugriwa.ac.id/index.php/ppg

Volume. 2, Nomor 1 Mei 2021; e ISSN: 2722-8614

\title{
PENDIDIKAN PROFESI GURU DALAM KAITANNYA DENGAN PENINGKATAN PROFESIONALISME GURU
}

\author{
Ni Nyoman Lisna Handayani ${ }^{1}$, Ni Ketut Erna Muliastrini ${ }^{2}$ I Putu Suardipa ${ }^{3}$ \\ STAHN Mpu Kuturan Singaraja ${ }^{1}$, Universitas Pendidikan Ganesha ${ }^{2}$ STAHN Mpu \\ Kuturan Singaraja ${ }^{3}$ \\ lisnahandayani201@gmail.com ${ }^{1}$ erna.muliastrini@undiksha.ac.id ${ }^{2}$ \\ putu.suardipa@yahoo.com ${ }^{3}$
}

Diterima 20 April 2021, direvisi 30 April 2021, diterbitkan 1 Mei 2021

\begin{abstract}
Abstrak
Perubahan paradigma pendidikan menjadi paradigma pembelajaran berkonsekuensi logis terhadap perubahan dalam pengelolaan proses pembelajaran. Proses perubahan ini berimplikasi pada tuntunan kualifikasi akademik, kualitas kompetensi akademik, dan kompetensi profesional pengelola proses pembelajaran tersebut. Dalam hal ini, pengelola proses pembelajaran adalah pendidik (guru). Guru adalah pendidik profesional dengan tugas utama mendidik, mengajar, membimbing, mengarahkan, melatih, menilai, dan mengevaluasi peserta didik pada pendidikan anak usia dini di jalur pendidikan formal, pendidikan dasar, dan pendidikan menengah. Pendidikan profesional harus memiliki kualifikasi akademik dan kompetensi sebagai agen pembelajaran. Kualifikasi akademik yang dimaksud adalah tingkat pendidikan minimal yang harus dipenuhi oleh seorang pendidik, sedangkan kompetensi sebagai agen pembelajaran pada jenjang pendidikan usia dini, dasar, dan menengah meliputi empat kompetensi, yaitu kompetensi pedagogik, kompetensi kepribadian, kompetensi profesional, dan kompetensi sosial, yang diperoleh pada Program Pendidikan Profesi Guru (PPG), setelah yang bersangkutan memiliki kualifikasi akademik setingkat sarjana (S1) atau Diploma empat (D4). Sesuai dengan kerangka acuan aspek legal sistem pendidikan nasional, mereka yang memiliki kualifikasi akademik sarjana (S1) pendidikan (S.Pd) yang mengikuti Pendidikan Profesi Guru dengan model bersamaan (concurrent), diharapkan dapat memiliki kompetensi akademik dan kompetensi profesional, yang berpeluang besar untuk dapat melahirkan guru - guru yang profesional.
\end{abstract}

Kata kunci : Pendidikan Profesi, Profesionalisme Guru

\begin{abstract}
A change of educational paradigm to learning paradigm has consequently linked to a change in the management of learning process. This change process implies that it necessitates an academic qualification, quality of academic competency, and professional competency of the learning process manager, in this case, the management is the teacher herself. A teacher is a professional educator was main task is to educate, to teach, to guide, to direct, to train, to asses, and to evaluate pupils within the formal education of early schooling children, primary education, and secondary education. A professional educator must possess academic qualification and competencies as he/she acts as an agent of learning. The academic qualification meant here deals with the minimum educational level required of the teacher, while competencies which are attached to the teacher
\end{abstract}




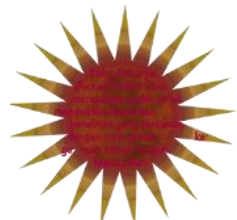 \\ Sang Acharya: Jurnal Profesi Guru \\ Universitas Hindu Negeri I Gusti Bagus Sugriwa \\ Denpasar \\ http: //ejournal. uhnsugriwa.ac.id/index.php/ppg \\ Volume. 2, Nomor 1 Mei 2021; e ISSN: 2722-8614}

teaching at primary and secondary educational levels encompass : pedagogical competency, personal competency, professional competency and social competency which are learnt in Professional Teacher Education, taken after S1 or Diploma 4 Degree has been gained. Within the legal reference of the national education system, for those having S1 degree in education (S.Pd) taken concurrently in a Professional Teacher Education are expected to have academic and professional competencies which in turn will provide them with greater chance to become professional teacher.

Keywords: Professional Education, Teacher Professionalism

\section{Pendahuluan}

Pembaharuan sistem pendidikan nasional telah ditetapkan visi, misi dan strategi pembangunan pendidikan nasional. Visi pendidikan nasional adalah terwujudnya sistem pendidikan sebagai pranata sosial yang kuat dan berwibawa untuk memberdayakan semua Warga Negara Indonesia, berkembang menjadi manusia yang berkualitas sehingga mampu dan proaktif menjawab tantangan zaman yang selalu berubah. Terkait dengan visi tersebut, telah ditetapkan serangkaian prinsip yang dijadikan landasan dalam pelaksanaan reformasi pendidikan.

Salah satu prinsip tersebut adalah bahwa pendidikan diselenggarakan sebagai proses pembudayaan dan pemberdayaan peserta didik yang berlangsung sepanjang hayat. Dalam proses tersebut harus ada pendidikan yang memberikan keteladanan dan mampu membangun kemauan, serta mengembangkan potensi dan kreativitas peserta didik. Prinsip tersebut menyebabkan adanya pergeseran paradigma proses pendidikan, dari paradigma pengajaran ke paradigma pembelajaran. Paradigma pembelajaran memberikan peran lebih banyak peserta didik untuk mengembangkan potensi dan kreativitas dirinya dalam rangka membentuk manusia yang mempunyai kekuatan spiritual keagamaan, berahlak mulia, berkepribadian, memiliki kecerdasan, memiliki estetika, sehat jasmani dan rohani, serta keterampilan yang dibutuhkan bagi dirinya, masyarakat, bangsa dan negara. Untuk dapat menyelenggarakan pendidikan berdasarkan paradigma tersebut, diperlukan acuan dasar pendidikan yang meliputi acuan filosofis, maupun acuan normatif baik yang bersifat kultural maupun lingkungan strategis.

Acuan filosofis didasarkan pada abstraksi acuan hukum dan kajian empiris tentang kondisi sekarang serta idealisasi masa depan. Secara filosofis, pendidikan perlu memiliki karakteristik : (1) mampu mengembangkan kreativitas, kebudayaan, dan peradaban, (2) mendukung diseminasi dan nilai keunggulan, (3) mengembangkan nilai-nilai demokrasi, kemanusiaan, keadilan dan keagamaan serta (4) mengembangkan secara kelanjutan kinerja kreatif dan produktif yang koheren dengan nilai- nilai moral. Semua ini tidak terlepas dari cita - cita pembentukan masyarakat Indonesia baru, yakni apa yang disebut dengan masyarakat madani.

Pendidikan kita harus pula memiliki acuan nilai kultural dalam penataan aspek legal. Tata nilai itu sendiri bersifat kompleks dan berjenjang mulai dari jenjang nilai ideal, nilai instrumental sampai pada nilai operasional. Pada tingkat nilai ideal, acuan pendidikan adalah pemberdayaan kemandirian dan keunggulan. 

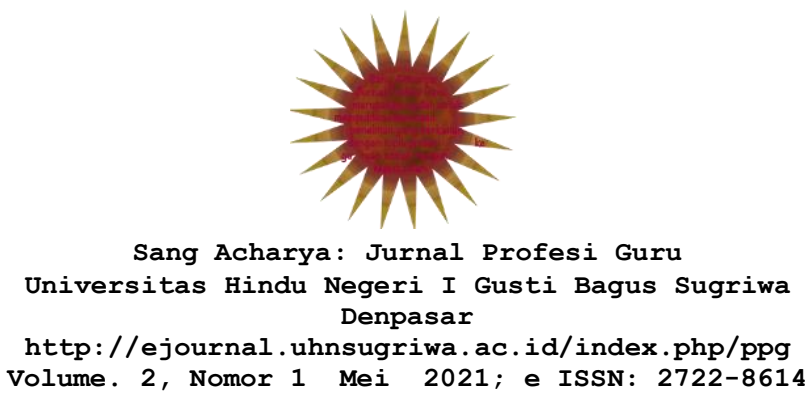

Pada tingkat instrumental, nilai-nilai penting yang perlu dikembangkan melalui pendidikan adalah otonomi, kecakapan, kesadaran berdemokrasi, kreativitas, daya saing, estetika, kearifan, moral, harkat, martabat dan kebanggaan. Pada tingkat operasional, pendidikan harus menanamkan pentingnya kerja keras, sportivitas, kesiapan bersaing, dan sekaligus bekerja sama dan disiplin diri.

Acuan lingkungan strategis mencakup lingkungan nasional dan lingkungan global. Dalam kaitan dengan lingkungan nasional, muncul nilai - nilai baru di masyarakat seperti kerja keras, keunggulan, dan ketepatan waktu, pengaruh politik yang sejak era reformasi terasa sangat labil, serta pengaruh ideologi dimana pendidikan ideologi perlu terkait dengan yang universal. Lingkungan nasional, yang saat ini masih dalam situasi reformasi, bertujuan untuk meningkatkan taraf hidup masyarakat. Secara nasional, acuan strategis ini mengandung arti bahwa pendidikan kita harus dapat menjawab tantangan reformasi dan membawa negeri ini keluar dari berbagai krisis.

Lingkungan global ditandai antara lain, dengan pesatnya perkembangan teknologi informasi sehingga kita tidak bisa menjadi warga lokal dan nasional saja, tetapi juga warga dunia. Lingkungan strategis sangat mempengaruhi bagaimana pendidikan masa depan tersebut hendaknya dirancang. Sebagai implikasi dari globalisasi dan reformasi tersebut, terjadi perubahan pada paradigma pendidikan. Perubahan tersebut menyangkut empat hal. Pertama, paradigma proses pendidikan yang berorientasi pada pengajaran dimana guru lebih menjadi pusat informasi, bergeser pada proses pendidikan yang berorientasi pada pembelajaran dimana peserta didik menjadi sumber (student center). Dengan banyaknya sumber belajar alternatif yang bisa menggantikan fungsi dan peran guru, peran guru berubah menjadi fasilitator. Kedua, paradigma proses pendidikan tradisional yang berorientasi pada pendekatan klasikal dan formal di dalam kelas, bergeser ke model pembelajaran yang fleksibel, seperti pendidikan dengan sistem jarak jauh. Ketiga, mutu pendidikan menjadi prioritas (berarti kualitas menjadi internasional). Keempat, semakin populernya pendidikan seumur hidup dan makin mencairnya batas antara pendidikan di sekolah dan di luar sekolah.

Dalam kaitan dengan hal tersebut, tidak bisa disangkal lagi bahwa pendidikan profesional guru merupakan suatu kerharusan. Secara eksplisit dalam penjelasan pasal 15 UU No.20/2003 tentang Sistem Pendidikan Nasional disebutkan bahwa pendidikan profesi merupakan pendidikan tinggi setelah program sarjana yang menyiapkan peserta didik untuk memiliki pekerjaan dengan persyaratan keahlian khusus. Ini berarti profesi guru terbuka, karena program Pendidikan Profesi Guru (PPG) bisa diikuti oleh semua kandidat yang telah menyelesaikan program sarjana. Pada pasal 10 UU No.14 Tahun 2005 tentang Guru dan Dosen juga menyebutkan bahwa kompetensi profesional guru diperoleh melalui pendidikan profesi. Hal di atas berimplikasi cukup serius bagi lembaga pendidikan tenaga kependidikan (LPTK) yang selama ini menyelenggarakan pendidikan guru dengan model bersama (concurrent). Apakah nantinya penganugerahan ijazah akta mengajar pada lulusan sarjana (S1) di bidang pendidikan bisa menggantikan sertifikat/ijazah pendidikan profesi yang dalam 


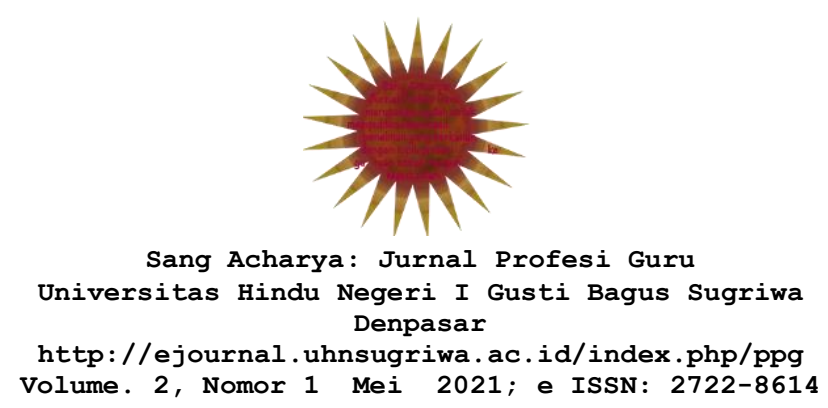

undang-undang semestinya diselenggarakan setelah program sarjana, ataukah setelah seseorang menyelesaikan sarjana (S1) pendidikan (S.Pd), menempuh lagi profesi pendidikan guru yang nantinya berujung dengan pemberiannya sertifikat/ijazah profesi. Pertanyaan selanjutnya, bagaimana penghargaan (kredit) terhadap bidang-bidang yang menyangkut profesi guru yang telah dimiliki oleh seseorang lulusan sarjana pendidikan? Berbagai pertanyaan lain muncul dalam kaitan dengan hal tersebut.

\section{Pembahasan}

\subsection{Tinjauan Mengenai Struktur Program Pendidikan Guru LPTK}

Konversi Intitusi Keguruan dan Ilmu Pendidikan (IKIP) Negeri Singaraja menjadi Universitas Pendidikan Ganesha menjadikan seluruh Lembaga Pendidikan Tenaga Kependidikan (LPTK) Negeri di Indonesia memangku mandat ganda (wider mandate), yaitu bertugas untuk mendidik tenaga kependidikan yang kompeten diberbagai jenjang (SD, SMP, dan SMA/SMK) di samping bertugas pula untuk menghasilkan tenaga terampil dan ahli diberbagai bidang di luar tenaga kependidikan. Bila diacu UU No 20/2003. PP No 19/2005, dan UU No 14/2005 ditekankan bahwa standar kompetensi lulusan digunakan sebagai pedoman dalam penentuan kelulusan. Dalam PP No 19/2005 pasal 25(4) dinyatakan bahwa standar kompetensi lulusan pada jenjang pendidikan tinggi bertujuan untuk mempersiapkan peserta didik menjadi anggota masyarakat yang berakhlak mulia, memiliki pengetahuan, keterampilan, kemandirian dan sikap untuk menentukan, mengembangkan, serta menerapkan ilmu, teknologi dan seni yang bermanfaat bagi kemanusian, sedangkan pada pasal 27 (1) dinyatakan bahwa standar kompetensi lulusan pendidikan tinggi ditetapkan oleh masing-masing perguruan tinggi. Ketentuan di atas menyiratkan besarnya otonomi akademik masing-masing perguruan tinggi, yang sudah pasti secara logis akan bermuara pada mutu yang dihasilkan. Dalam kaitan dengan itu, bagaimana LPTK khususnya yang memiliki wider mandate menentukan standar kompetensinya? Hal tersebut perlu dipikirkan lebih dalam oleh LPTK, dan pada tulisan ini khusus dianalisis tentang standar kompetensi tenaga pendidik (guru) yang merupakan salah satu tugas inti LPTK.

Guru adalah pendidik profesional dengan tugas utama mendidik, mengajar, membimbing, mengarahkan, melatih, menilai dan mengevaluasi peserta didik pada pendidikan anak usia dini jalur pendidikan formal, pendidikan dasar, dan pendidikan menengah. Pendidikan profesional harus memiliki kualifikasi akademik dan kompetensi sebagai agen pembelajaran. Kualifikasi akademik yang dimaksud adalah tingkat pendidikan minimal yang harus dipenuhi oleh seorang pendidik, yang dalam kaitan dengan pendidikan dasar dan menengah adalah sarjana (S1) atau diploma empat (D4). Kompetensi sebagai agen pembelajaran pada jenjang pendidikan dasar, menengah dan usia dini meliputi empat kompetensi, yaitu kompetensi pedagogik, kompetensi kepribadian, kompetensi 

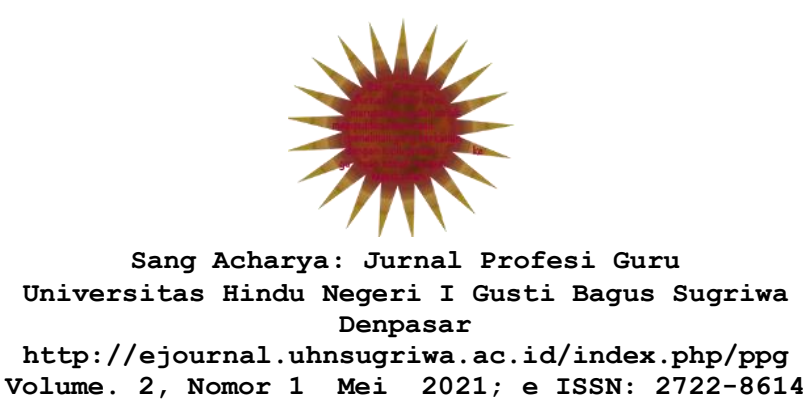

profesional dan kompetensi sosial (PP 19/2005 ps 28 ayat 3). Inilah yang mendasari terbukanya peluang pendidikan guru model konsekutif, karena; setelah seseorang memiliki kualifikasi akademik tertentu, dan bila yang bersangkutan ingin mengabadikan dirinya sebagai pendidik, yang bersangkutan bisa melakukan dengan menambah kemampuannya dengan menguasai/memiliki kompetensi keguruan, yang diformat dalam Program Pendidikan Profesi Guru (PPG). Bila demikian persoalannya bagaimana eksistensi program pendidikan tenaga kependidikan yang mengahasilkan sarjana (S1) pendidikan (S.Pd) yang selama ini menempuh pendidikan guru dengan model bersama (concurrent)?

Mengkaji persoalan di atas, tampaknya LPTK harus tetap memperjuangkan model bersamaan (concurrent) sebagai model pendidikan guru di LPTK, dan bila mungkin dikembangkan sehingga dapat menjadikan program pendidikan di LPTK multy entry dan multy exit, yang secara diagramatik diusulkan seperti visualisasi

berikut.

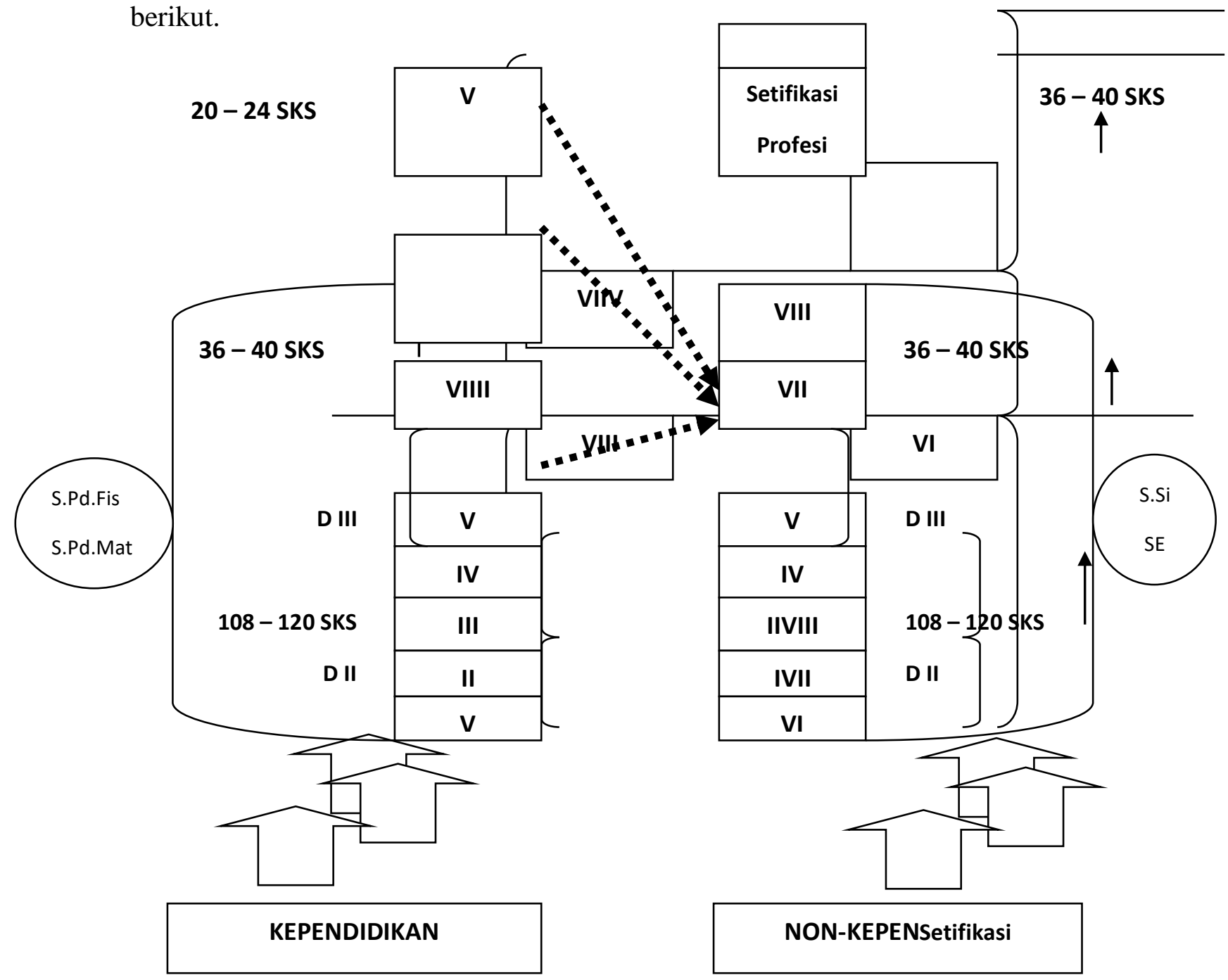



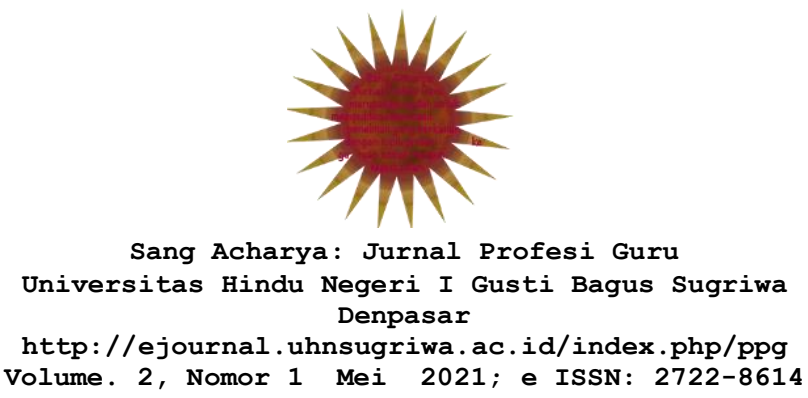

\section{Keterangan:}

(1) Untuk semua jenis kualifikasi (kependidikan maupun non kependidikan), dari semester I sampai dengan semester VI diberikan materi bidang studi dengan bobot SKS yang sama, yaitu berkisar antara 108 - 120 SKS.

(2) Memasuki semester VII sampai dengan semester VIII, untuk jenis kualifikasi kependidikan diberikan mata kuliah bidang studi dan pendidikan profesi antara 36-40 SKS (16 SKS pendidikan profesi I, dan 24 bidang studi), sedangkan untuk jenis kualifikasi non kependidikan, diberikan materi bidang studi (keilmuan) antara 36-40 SKS.

(3) Total SKS yang harus diselesaikan oleh seorang mahasiswa untuk memperoleh gelar kesarjanaan, baik sarjana pendidikan maupun sarjana nonkependidikan berkisar antara 144-160 SKS (penetapan yang baru belum keluar).

(4) Bagi sarjana pendidikan, untuk menempuh pendidikan profesi II, mereka diwajibkan untuk mengikuti kuliah dengan beban 24 SKS untuk memperoleh pendidikan profesi II yang berujung dengan mendapatkan sertifikat profesi pendidik (prasyarat untuk dapat diterima sebagai "pelamar" tenaga pendidik (guru) sesuai dengan UU Guru dan Dosen, serta PP 19/2005, yang kisarannya kurang lebih 1 tahun.

(5) Bagi sarjana nonkependidikan, untuk memperoleh sertifikat profesi pendidik, mereka diwajibkan untuk mengikuti perkuliahan dengan beban 36-40 SKS. Sertifikat profesi ini akan menunjukkan bahwa seseorang berwenang sebagai guru bidang studi tertentu sesuai dengan kualifikasi keilmuannya, dan bidang studinya harus linier, yang ditempuh selama \pm 1,5 tahun. Contoh, seorang lulusan sarjana fisika, untuk memperoleh kewenangan sebagai guru fisika, dia harus mengambil pendidikan profesi bidang pendidikan fisika.

(6) Bagi mahasiswa, baik yang awalnya berada pada jalur kependidikan maupun non kependidikan, bilamana mereka "berhenti" mengikuti program perkuliahan minimal setelah menyelesaikan pendidikannya selama 1 tahun (akhir semester 2, dengan tambahan beberapa SKS bidang keterampilan vokasi, dapat dirancang untuk mendapatkan sertifikat Diploma I atau disesuaikan dengan "titik" dimana mereka berhenti, dengan catatan bahwa mereka wajib mengikuti program praktek lapangan atau program lain yang dirancang oleh masing-masing Jurusan/Prodi. Setelah persyaratan itu dipenuhi, mereka berhak mendapatkan sertifikat Diploma tertentu.

(7) Bagi mahasiswa yang di awal masuknya memilih jenis kualifikasi kependidikan setelah mengakhiri semester VI (akhir tahun ke-3), dimungkinkan untuk pindah jalur ke non-kependidikan, sehingga mereka nantinya keluar sebagai sarjana nonkependidikan (keilmuan).

(8) Pengorganisasian sebaran kompetensi ke dalam elemen kompetensi dirumuskan oleh masing-masing Jurusan/prodi sehingga sesuai dengan visi dan misi yang diembannya. 


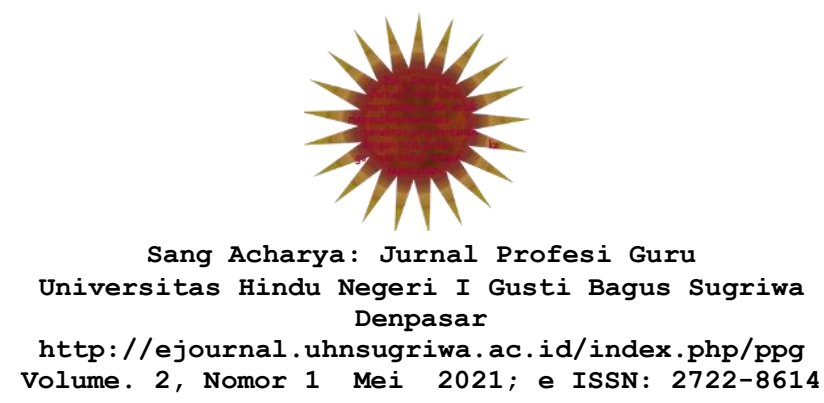

(9) Untuk standarisasi isi dan proses, perlu dibentuk "tim khusus" dari masing masing Jurusan/Prodi, sehingga akuntabilitas akademik dan sosialnya dapat ditinggikan serta sesuai dengan tuntutan ke depan.

(10) Adapun contoh sebaran kompetensi dan elemen kompetensi yang saat ini masih diberlakukan sesuai dengan "kebijakan formal bidang pendidikan" dapat dijabarkan sebagai berikut. Jumlah keseluruhan beban untuk pendidikan profesi, baik untuk jenis kualifikasi kependidikan maupun nonkependidikan adalah 36-40 SKS, namun sebaran dan waktu pemunculannya (penawarannya) yang berbeda. Jika pada jalur kependidikan, dimunculkan pada semester VII, VIII, IX dan X dan bahkan mungkin sebelumnya, maka untuk jalur nonkependidikan dirancang dalam 3 (tiga) semester, yaitu pada semester IX, X, dan XI.

\subsection{Kompetensi Lulusan Program S1 LPTK}

Pengalaman yang didapatkan oleh kalangan Pendidikan Tinggi di tahun 1980an, melalui program rintisan pengadaan guru MIPA setingkat D3, yang dikelola oleh beberapa perguruan tinggi Pembina (istilah saat itu), yang menghasilkan kualitas lulusan (output) yang "biasa-biasa saja”(tidak berada di atas kualitas lulusan yang dikelola oleh LPTK), dapat digunakan dasar yang kuat untuk menduga bahwa perancangan pendidikan guru model konsekutif tidak akan memberikan kontribusi yang signifikan terhadap kualitas calon guru yang dihasilkan, dan dengan berbagai alasan yang mendasari khususnya familiaritas keguruannya yang dapat dibina sejak awal tanpa mengesampingkan penguasaan bidang keilmuannya, maka sangat mendasar program pendidikan guru model bersamaan/terintegrasi dipertahankan/konsisten dilaksanakan sebagai program pendidikan guru di LPTK. Diagram tahapan pelaksanaan model tersebut diusulkan untuk dikaji seperti digambarkan pada diagram di atas.

Kajian mengenai aspek legal program sangat perlu dicermati karena hal itu akan berhubungan langsung dengan keabsahan ouput suatu program. Diagram yang diajukan memberi peluang lulusan sarjana (S1) pendidikan mendapatkan ijazah sarjana dan penambahan program pendidikan profesi maksimal selama dua semester yang berujung dengan pemberian sertifikat profesi pendidik, memenuhi aspek legal lulusan untuk melamar menjadi pendidik (guru). Dalam kaitan dengan kualifikasi akademik program sarjana (S1) pendidikan, perlu dirancang kompetensi lulusan program tersebut. Menurut penulis, empat kompetensi yang tertera pada PP 19/2005 pasasl 28 (3) adalah merupakan kompetensi pendidik sebagai agen pembelajaran, yang semestinya diterjadikan pada program pendidikan profesi guru. Oleh karena itu, dalam rangka rancangan multy entry dan multy exit dari program sarjana (S1) pendidikan di LPTK, di samping untuk memperkuat segi kualitas akademik lulusan, diajukan dua kompetensi pada tingkat program sarjana (S1) pendidikan, yaitu kompetensi akademik, dan kompetensi profesional. 


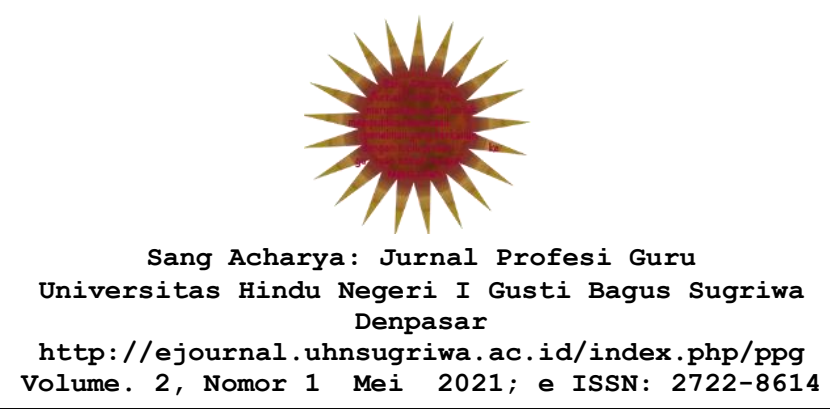

Berbicara secara umum, kompetensi merupakan seperangkat pengetahuan sikap, keterampilan dan perilaku yang harus dimiliki, dihayati dan dikuasai oleh guru dalam melakukan tugas keprofesionalannya, sedangkan profesional adalah pekerjaan atau kegiatan yang dilakukan oleh seseorang dan menjadi sumber penghasilan kehidupan yang memerlukan keahlian, kemahiran atau kecakapan yang memenuhi standar mutu atau norma tertentu serta memerlukan pendidikan profesi (Ketentuan Umum UU No.14 Thn 2005). Ketentuan di atas secara eksplisit menyiratkan bahwa profesi guru terkait dengan konteks layanan ahli dalam bidang keguruan-kependidikan karena terapan layanan ahli kependidikan itu selalu berlandaskan penguasaan akademik yang solid. Gane (1978) melukiskannya sebagai "seni yang terapannya berbasiskan sains". Secara sederhana dapat dilukiskan, dalam suatu interaksi dalam pembelajaran, seorang guru profesional minimal harus mempertanyakan pada dirinya, apa yang akan dia lakukan dalam proses interaksi tersebut, bagaimana dia melakukannya, dan kenapa demikian dia melakukannya. Ini berarti, dalam pelaksanaan layanannya, seorang pengampu layanan ahli, harus peduli dengan sisi Why (menyangkut tujuan pendidikan), sisi How (menyangkut prosedur), dan sisi When (menyangkut konteks). Interaksi dalam pembelajaran bersifat transaksi situasional, yang pada dasarnya merupakan suatu perjumpaan budaya antara pendidik dan peserta didik, yang memang telah dipelajari dan dibawanya secara alamiah di lingkungannya masing-masing. Oleh karena itu, guru yang mengelola proses pembelajaran harus mengerahkan penguasaan akademiknya yang utuh (yang bukan hanya sebatas penguasaan keilmuan bidang studi/disclipinary content saja), tetapi harus mengutamakan tercapainya kemaslahatan peserta didik yang memiliki kerakteristik tertentu, dan menguasai dengan cermat berbagai pendekatan dalam pengambilan keputusan dalam situasional pembelajaran.

Dalam kaitannya dengan hal di atas, seorang guru seyogyanya menguasai karakteristik peserta didik yang diampu dan dilayani secara mendalam dengan berbagai variasi karakter dan cara pendekatannya, menguasai bidang ilmu sumber (bahan ajar) dari segi disclipinary content maupun pedagogical content, menguasai pendekatan pembelajaran yang mendidik dan memandirikan baik menyangkut perancangan, maupun implementasinya, serta mengembangkan kemampuan profesional secara berkelanjutan. Penguasaan dimensi-dimensi konsep akademik yang berhubungan dengan layanan ahli keguruan-kependidikan tersebut serta pengalaman mengaplikasikan dalam profesinya sebagai guru, akan menimbulkan secara berkelanjutan nurturant effects pada kemampuan sosial dan kemampuan personal yang pada gilirannya akan berkontribusi pada kepribadian guru secara makro. Oleh karena itulah, perancangan pada kepribadian guru secara prioritas sebenarnya bertumpu pada penggarapan kemampuan akademik dan kemampuan profesional (yang seyogyanya harus diartikan sebagai kemampuan penerapan bidang akademik dalam kancah profesi yang menjadi garapan layanan ahli keguruan-kependidikan, bukan justru penguasaan disciplinary content yang seyogyanya tidak ditampilkan terpisah dari bidang garapan profesi). Dari proses pendidikan yang secara tekun dan konsisten mempedomani penggarapan 

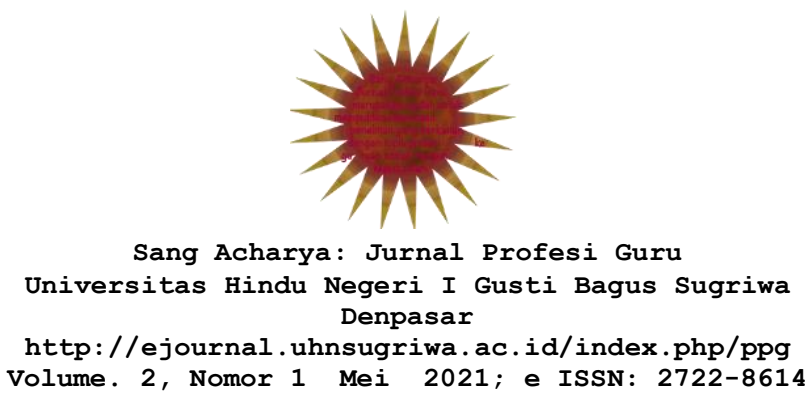

kemampuan akademik dan profesional tersebut, disertai dengan cara-cara pengelolaan proses transformasi itu yang dapat menimbulkan interaksi pembelajaran yang inspiratif, interaktif, menantang, menyenangkan, memotivasi (I2M3) dan memberikan teladan, akan terbentuk pengaruh pengiring (nurturant effects) pada kemampuan personal maupun kemampuan sosial, minimal yang terkait dengan kancah garapan layanan ahli keguruan-kependidikan. Dengan mempertimbangkan dan mempersilahkan model konsekutif dalam pendidikan profesi guru dilaksanakan (yang memang peluangnya dibuka oleh aspek legal), maka sangatlah wajar LPTK tetap memperjuangkan model pendidikan bersamaan/integrative (concurrent) bagi pendidikan guru di tanah air yang memang juga peluangnya dimungkinkan pada UU No.14/2005), dan jangan justru dinafikan bahwa LPTK cukup atau dianggap cukup sibuk hanya dengan mengelola pendidikan profesi pendidik (guru) yang konon diperkirakan akan berlimpah ruah dengan para calon mahasiswa yang akan mengikuti pendidikan profesi pendidik (guru) dengan pola konsekutif. Bila hal terakhir itu memang benar terjadi, berarti lonceng kematian bagi eksistensi kelembagaan dan keilmuan LPTK yang belum lagi disikapi secara tidak proporsional dalam pengembangan programnya setelah menjalani fungsi perluasan mandat (wider mandate). Hal ini perlu ditekankan supaya LPTK jangan mudah tergelincir secara tidak proporsional, dan bahkan meninggalkan tugas utamanya.

Kompetensi akademik diajukan dengan prinsip penguasaan disciplinary content dan pedagogical content secara mengorkestra, yang dapat dijabarkan ke dalam subkompetensi (1) kemampuan mengenal peserta didik secara mendalam, (2) penguasaan bidang studi yang menyangkut substansi dan epistimologi keilmuan (disciplinary content), dan pengemasan bidang keilmuan tersebut menjadi bahan ajar sesuai dengan konteks kurikuler maupun karekteristik peserta didik (dalam subkompetensi inilah peluang LPTK untuk mengkriet dan memvariasi programnya menjadi multy exit sehingga menjadi menarik dan sesuai kebutuhan lapangan), (3) kemampuan menyelenggarakan pembelajaran yang mendidik, yang mampu memfasilitasi pembentukan kemampuan yang utuh yang mampu memadukan antara dimensi pengetahuan (faktual, konsep, prosedural, dan metakognitif) dengan dimensi proses (pengetahuan, pemahaman aplikasi, analisis/mengkaji, evaluasi dan mencipta) seperti yang dikemukakan Anderson \& Krathwohl (2001), sehingga pembentukan sikap dan keterampilan kognitif, personal dan sosial maupun psikomotorik yang diperoleh melalui latihan menjadi terbentuk secara utuh, dan (4) kemampuan mengembangkan keterampilan profesional secara berkelanjutan. Hal ini harus tertanam menjadi kebiasaan dan sikap profesional guru dalam kesehariannya, yang didapatkan berdasarkan hasil refleksi dari dampak kinerjanya (reflective practitioner).

Kompetensi profesional merupakan kemampuan untuk menerapkan kompetensi akademik dalam kancah profesi keguruan-kependidikan, yang diimplementasikan melalui pengalaman lapangan (PPL) secara bertahap dari, pengenalan lapangan, pelatihan keterampilan dasar mengajar, latihan terbimbing, 


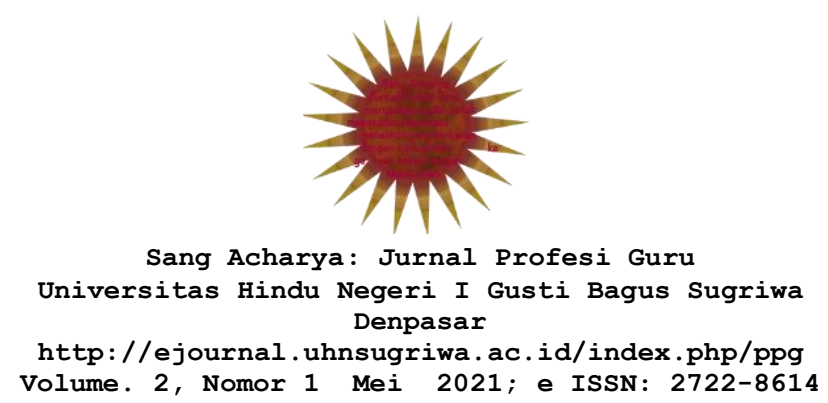

latihan penugasan terstruktur, dan latihan mandiri, dalam kaitannya dengan pengelolaan pembelajaran (merencanakan, melaksanakan, mengevaluasi, dan memonitoring proses pembelajaran) dan keterampilan membina hubungan sosial dengan siswa, teman sejawat dan orang tua peserta didik. Dengan demikian subkompetensi profesional ini meliputi (1) keterampilan menerapkan kompetensi akademik dalam proses pembelajaran dan (2) keterampilan berhubungan sosial dengan pihak terkait dalam rangka peningkatan dan efektivitas pembelajaran yang mendidik. Keterampilan (kompetensi) personal merupakan unsur kunci bagi guru profesional, sehingga menjadi unsur kunci pula dan termasuk dalam subkompetensi profesi guru, karena; bila ditelusuri lebih jauh pembentukan kompetensi ini bukanlah merupakan dampak instruksional effect dari suatu pendidikan formal yang diikuti calon guru. Ia lebih banyak merupakan nurturant effects dari pencapaian kompetensi akademik dan kompetensi profesional, dan bahkan juga telah terbentuk dasar-dasarnya dari pendidikan sebelumnya, baik di lingkungan keluarga maupun masyarakat. Dengan demikian, kompetensi personal ini dapat dideskripsikan dengan indikator beriman dan taqwa, berahlak mulia, arif demokratis, mantap, berwibawa, stabil, dewasa, jujur dan sportif, yang terjadi bersenyawa pada saat proses pencapaian kompetensi akademik dan profesional. Dua standar kompetensi (kompetensi akademik dan profesional) diusulkan menjadi landasan dasar kualifikasi akademik seseorang sarjana (S1) pendidikan (S.Pd), dan masing-masing sub-kompetensi yang diuraikan di atas menjadi kompetensi dasar, yang nantinya dalam proses pengembangan lanjut digunakan sebagai dasar pengembangan materi sebagai muara dari pengalaman belajar yang harus didapatkan. Dengan penguasaan kualifikasi akademik seperti itu, di samping memenuhi aspek legal, model bersamaan (concurrent) dalam pendidikan guru dapat diselenggarakan secara konsisten, karena kontinuitas program tersebut merupakan landasan yang kokoh seseorang (S.Pd) untuk menjalani pendidikan profesi guru. Proses pendidikan seperti itu akan memberi peluang yang lebih besar untuk menghasilkan calon-calon guru yang profesional, ketimbang hanya menumpangkan (on top) program pendidikan profesi guru setelah seseorang menguasai kualifikasi akademik tertentu yang dari semula dalam proses pembelajarannya sama sekali tidak pernah mambumi dengan profesi keguruan. Walaupun demikian, dalam perkembangannya ke depan pendidikan profesional guru (prajabatan) pola bersamaan (concurrent) dan begitu pula pola konsekutif, malah akan ditugaskan pada LPTK, karena hal tersebut telah teramanatkan dalam perundangan, dan hal ini harus dijadikan kesempatan yang sangat berharga bagi LPTK, karena akan mendapat pengalaman yang berharga untuk mencermati kedua model pendidikan profesi guru.

\section{Kesimpulan}

Dengan adanya otonomi akademik di perguruan tinggi, jelas akan terdapat kreasi program pada masing-masing perguruan tinggi LPTK. Akan tetapi, 


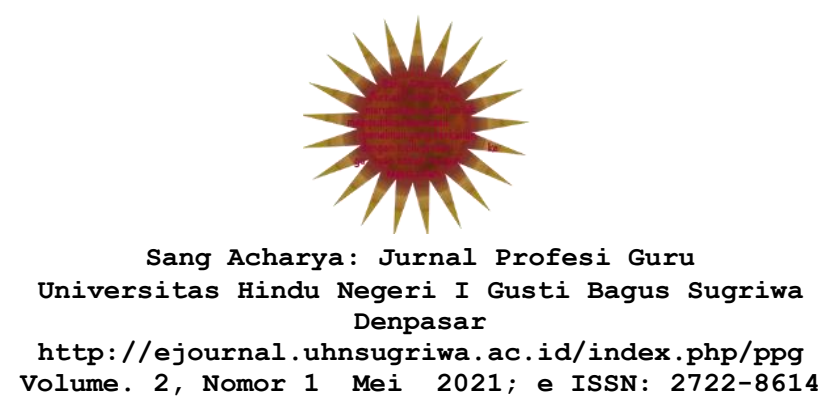

pendidikan profesional guru terintegrasi harus tetap merupakan program baku, yang berorientasi pada pembentukan kompetensi akademik yang harus dapat ditampilkan secara mengorkestra antara disciplinary content dan pedagogical content, yang bila mengacu aturan yang berlaku sebelum PP 19/2005, adalah minimal 144 SKS dan maksimal 160 SKS ditempuh selama kurun waktu minimal 4 tahun. Setelah itu, secara khusus ditambahkan antara satu sampai dua semester untuk melakukan program pengalaman lapangan yang merupakan fortifikasi kompetensi profesional. Dalam pelaksanaannya, pada paruh waktu delapan semester pertama, harus diramu secara proporsional komponen-komponen yang mendukung tercapainya kompetensi akademik dan kompetensi profesional, yang selanjutnya dalam satu/dua semester terakhir hanya dilakukan untuk pemantapan penguasaan kompetensi profesional. Hal ini perlu dilakukan secara serius, di samping untuk mengantisipasi suara sumbang bahwa penguasaan content keilmuan pada pendidikan guru terasa kurang, juga untuk bisa menyiapkan guruguru yang profesional dalam kancah profesi keguruan-kependidikan, yang sudah pasti secara berlanjut akan berpengaruh terhadap pembentukan kualitas sumberdaya manusia.

Memang semua hal di atas akan berimplikasi pada pengelolaan kelembagaan di LPTK (yang saat ini memangku perluasan mandat) yang harus mampu juga mengelola antara program pendidikan (DIK) dan program nonkependidikan (NON DIK) sehingga muncul mutual kontribusi antar program tersebut. Di satu pihak program DIK dapat memberi penguatan dalam bidang pendekatan pembelajaran pada program NON DIK, dan pihak lain program NON DIK dapat memberikan kontribusi yang signifikan pada peningkatan kualitas penguasaan keilmuan bidang studi. Hal ini perlu dijaga secara memadai, dan bukan harus dipertentangkan kehadirannya (yang biasa berpotensi buruk pengaruhnya pada suasana akademik). Dengan kewenangan yang dimiliki oleh masing- masing perguruan tinggi LPTK untuk mengelola sendiri ditambah kreasi yang maksimal dari pengelola lembaga, sangat besar peluang bahwa pengembangan kedua program tersebut mencapai sasaran yang sesuai dengan harapan.

Dengan itikad baik untuk dapat melahirkan calon-calon guru profesional yang menurut istilah Glickman berada di kuadran satu, semoga nantinya muncul fenomena yang menarik, menantang dan memotivasi LPTK itu sendiri dalam melaksanakan profesional guru dalam pola terintegrasi (concurrent) dan melaksanakan pendidikan profesional guru dengan pola konsekutif (consecutive). Demikianlah hal ini dikemukakan sebagai bahan pemikiran, semata demi penghargaan profesionalisme keguruan-kependidikan di tanah air.

\section{Daftar Pustaka}

Anderson, Orin W. And Krathwohl, David R. 2001. A Taxonomy for Learning, Teaching and Assessing. New York: Addison Wesley Longman, Inc. 


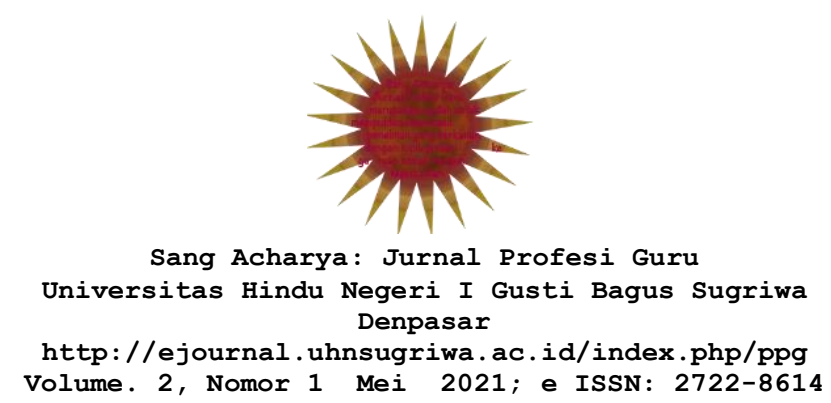

Gage, N.L. 1978. The Scientific Basis of The Art of Teaching. New York : Teachers Collage Press.

Hogan-Garcia, M. 2003. The Four Skills of Csistemal Diversity Competence : A Process for Understanding and Practice. Pacific Grovve, CA : Brooks/Cole

Peraturan Pemerintah Nomor 19 Tahun 2005 tentang Standar Nasional Pendidikan. Jakarta : Departemen Pendidikan Nasional.

Raka Joni, T. 1983. Cara Belajar Siswa Aktif, Wawasan Kependidikan dan Pembaharuan Pendidikan Guru, Pidato Penerimaan jabatan Guru Besar pada FIP IKIP Malang. Malang : IKIP Malang.

Raka Joni, T. 2006. Revitalisasi Pendidikan Profesional Guru. Jakarta : Direktorat Jenderal Pendidikan Tinggi.

Undang-undang Republik Indonesia Nomor 20 Tahun 2003 tentang Sistem Pendidikan Nasional. Jakarta : Departemen Pendidikan Nasional.

Undang-undang Republik Indonesia Nomor 14 Tahun 2005 tentang Guru dan Dosen. Jakarta : Departemen Pendidikan Nasional. 